\title{
Articles
}

\section{EMPIRICAL TEST OF THE EFFICIENCY OF CURRENCY INVESTMENTS}

\author{
Svend Reuse, Martin Svoboda*
}

\begin{abstract}
:
The portfolio theory and the basic ideas of Markowitz can be applied to currency investments as well as to classical asset classes as shares or bonds. The question whether currency investments can be treated as efficient asset classes is not finally answered in theory and practice. This article applies a modified historical simulation approach to shares, bonds and currencies. The questions according to the efficiency of currency investments are answered empirically from a euro-investor's point of view. The empirical analysis leads to the result that currency investments are not efficient in general. Some specific cases exist. The used data lead to the result that the Czech koruna seems to be an efficient asset class and leveraging a euro portfolio by other currencies is useful as well. But it has to be doubted if these effects will remain in the future.
\end{abstract}

Keywords: portfolio theory; financial crisis; historical simulation; currency investment; leveraging by currencies.

JEL Classification: F 31, G11, G 14, G15

\section{Introduction and Problem Definition}

In an international portfolio selection, currency investments have to be taken into account. The question whether currency investments can be treated as efficient asset classes is not finally answered in theory and practice (Reuse, 2009, p. 273). On the one hand, passive management styles neglect currencies as investments form, because they are considered as inefficient. This is supported by the underperformance of currency funds. On the other hand, currencies show relatively low correlations to other assets,

* Svend Reuse, FOM University of Applied Science; Masaryk University Brno, CR; Sparkasse Mülheim an der Ruhr, Luxemburger Allee 121, DE - 45481, Mülheim (Svend.Reuse@gmx.de). Martin Svoboda, Masaryk University Brno, Lipova 41a, CZ - 602 00, Brno (svoboda@econ.muni.cz). 
so that an asset allocation by using currency investments may be useful (Bleuel, 2006, p. 1059).

This paper answers this question empirically from a euro-investor's point of view. Several currencies, only combined with the relevant money market, are compared to the share index investment and the typical euro-bond investment. While the share index is represented by the German DAX (Deutscher Aktienindex), the euro bond is modelled by the German RexP (Rentenperformance Index).

Therefore the structure is as follows. Section two explains the used theory in a short way. Efficient asset classes, the basics of portfolio theory and the historical simulation are described. Further, basic ideas according to macroeconomic behaviour of currency prices and interest rates are presented.

Sections three and four build the main parts of this article as they explain the empirical analysis based on historical data for several countries, following the main ideas of the DSGV (Deutscher Sparkassen- und Giroverband). Three main aspects are analysed:

1. Are currency investments efficient portfolios?

2. Does a portfolio selection considering currency investment lead to a diversified and thus efficient portfolio?

3. Does leveraging a portfolio by refinancing it with another currency lead to an efficient portfolio?

Section five sums up the main results, answers these questions and offers a critical outlook.

\section{Used Theoretical Aspects of Portfolio Theory and Macroeconomy}

\subsection{Definition of Risk and Value at Risk}

Whenever the discussion about portfolio diversification and risk minimization occurs, the first step is to define risk. In general, risk is the positive or negative unexpected difference from an expected value. The positive difference is called a chance, so only the negative difference from the expected value remains (Rolfes, 2008, p. 8; Reuse, 2008, p. 5). This leads to the result that expected changes from the actual value of an asset are not defined as risk.

A method to measure risk is the VaR (Value at Risk). It can be defined as the unexpected loss that will not be exceeded within a certain time under the assumption of a defined security level, called confidential level (Schierenbeck, 2001, p. 17). This definition leads to several factors that influence the VaR. In general, it can be stated that the VaR will increase, if the disposition period becomes longer and the confidential level gets higher (Reuse, 2006, p. 366). The model used to measure the risk influences the VaR as well, but this depends on the risk category and not on the basic assumptions to measure risk (Rolfes, 2008, p. 106). 


\subsection{Efficient Portfolios}

In order to define efficient asset classes, the related expected yield and risk have to be analysed. Therefore the Sharpe ratio (Sharpe, 1964; Sharpe, 1994) can be used. In modern risk management, a similar figure is used. It is called RORAC (Return on Risk Adjusted Capital) and it is defined similar to the Sharpe ratio (Rolfes, 2008, p. 68; Pohl and Schierenbeck, 2008, p. 11), but inserting the VaR instead of the standard deviation into the formula:

$$
R O R A C=\frac{r_{A}-r_{f}}{V a R_{A}}
$$

with:

$r_{A}=$ (expected) return of the asset class

$r_{f} \quad=$ risk free return

$\operatorname{VaR}=$ Value at Risk of the asset class

This term will be used in sections three and four. It has to be kept in mind that the model normally requires expected yields while this article focuses on historical yields.

\subsection{Portfolio Selection}

Beneath the question, whether currencies may form efficient asset classes in an isolated view, the portfolio selection by including currencies shall be analysed as well.

The origin of the portfolio theory can be found in 1952 (Markowitz, 1952, p. 77; Markowitz, 1987, p. 3). Markowitz demonstrates how an investor can reduce the risk respectively the standard deviation of the portfolio returns by choosing stocks that do not move exactly together.

The portfolio theory analyses the situation of investment decisions considering risk by using the principle of $\mu \sigma$ : The volatility can be seen as a degree of risk if all shares can be described by the expected returns $(\mu)$ and the volatility $(\sigma)$ of returns. The theory assumes risk-averse behaviour of investors, which means that they are willing to renounce with return in favour of reducing the risk of an investment. A portfolio is consequently risk efficient if there is no alternative to get less $\sigma$ for the same $\mu$, more $\mu$ for the same $\sigma$ or both more $\mu$ and less $\sigma$. The basic idea lying behind this is that a diversified risk is always smaller than the weighted sum of the risks if the correlation between the assets is smaller than one. Markowitz argues with covariances and variances of portfolios instead of correlation effects and standard deviations but he can be cited as follows: "If two original portfolios have equal variance then typically the variance of the resulting (compound) portfolio will be less than the variance of either original portfolio (Markowitz, 1952, pp. 89 - 90)."

\subsection{Historical Simulation}

Markowitz uses the standard deviation to quantify risk. Further, he assumes a normal distribution. Both assumptions cannot be used in risk management as risk is underestimated by using a normal distribution and measuring risk on an $84.5 \%$ 
confidential level. If enough data is available, the historical simulation shall be used.

In order to prevent the normal distribution assumption, the historical simulation goes one step further. It uses a "real" distribution without converting historical data into a distribution function. It defines risk as the difference from an expected value. A further advantage is that extreme changes in the history that exist above the chosen confidential level can be measured as well as they are not converted into a distribution function. The real distribution differs from the normal distribution function.

As a consequence, historical yields are used to measure risk. Therefore the procedure is less analytical than the variance/covariance approach but the needed data are much higher (A critical analysis of several VaR methods can be found in Goebel, Sievi, Schumacher, 1999, p. 236).

It works as follows (Bühler, Korn, Schmidt, 1998, p. 68): the historical price developments are transformed into lognormal yields. Yields of a specific history for all assets build a yield set. All yield sets that are evaluated by this way - typically several thousands - are added to the existing portfolio. Thousands of virtual portfolio changes can be defined. They are sorted by height and the needed quantile is defined by counting these changes. Applying this on a portfolio leads to the conclusion that this procedure must be done for all asset combinations for the given historical yields. The advantage is that extreme movements can be analysed concretely and that only changes that appeared in the past are interpolated into the future.

\subsection{Macroeconomic Impulses for the Performance of Currencies}

Currency risk and chances result from several arguments that have economic and financial background. The central assumption in macroeconomy and finance is that interest rate developments and exchange rate volatilities compensate each other (Blanchard and Illing, 2003, p. 528). This section structures and defines factors that influence both of them. These factors support the main assumption of Blanchard and Illing. The consequence for portfolio management is that currency investments cannot be efficient as the interest rate effect corresponds to the currency effect in the long run.

First, the country risk has to be mentioned. While sovereign risk defines the default risk of a sovereign (Krämer-Eis, 1998), country risk in its general definition sums up all additional risks a foreign debtor compared to a domestic investor has. Exchange rate volatilise may result from both forms of country risk. The higher the risk of a sovereign or of a country is, the higher the offered interest rate shall be, according to its country or sovereign rating (Cezanne, 1997, p. 624).

The balance on current account influences the exchange rate as well. The higher the net imports into a country are, the less the domestic currency is worth.

In the context of the purchasing power parity (Cassel, 1932, p. 456), inflation has a high impact onto the exchange rate (discussed in Gontermann, 2005, p. 887). In this model, the exchange rate differential equals the inflation differential. Dornbusch extended the origin PPP model. He combined monetary and economic components. Beneath the inflation, productivity and other factors and integrated into the model (Dornbusch, 1976).

In the context of the interest rate parity, expected exchange rate differential equals the interest rate differential (Kempa, 2001). This leads to an equilibrium at the markets 
as an investor will only invest into a currency, if an expected devaluation of the currency is compensated by a higher return (Rittenbruch 1995, p. 334). The interest rate parity can be divided into the covered and uncovered interest rate parity. The uncovered interest rate parity assumes that investors do not hedge exchange rate risk. The covered interest rate parity hedges exchange rate risk by using the forward market. By this, equilibrium can be generated so that the exchange rate differential equals the interest rate differential. The covered interest rate parity can be shown empirically, the uncovered interest rate parity is not fully proven (Kempa, 2001, p. 956).

Structuring these aspects leads to Table 1 that sums up those factors that influence currency prices and interest rate levels.

Table 1

Impacts on Currency and Interest Rate Movements

\begin{tabular}{|l|c|l|c|}
\hline \multicolumn{2}{|l|}{ Macroeconomic Impulses } & \multicolumn{2}{l|}{ Impacts onto: } \\
\hline Factor & Changes & Exchange Rate & Interest Level \\
\hline inflation & $\uparrow$ & devaluation & $\uparrow$ \\
\hline home key interest rate & $\uparrow$ & revaluation & $\uparrow$ \\
\hline gross domestic product & $\uparrow$ & revaluation & $\uparrow$ \\
\hline export & $\uparrow$ & revaluation & $\downarrow$ \\
\hline $\begin{array}{l}\text { money in circulation - } \\
\text { relative change to other countries }\end{array}$ & $\uparrow$ & devaluation & $\uparrow$ \\
\hline expectations of investor: & Yield $\uparrow$ & revaluation & --- \\
\hline expectations of investor: & Exchange rate $\downarrow$ & devaluation & $\uparrow$ \\
\hline country risk & $\uparrow$ & devaluation & $\uparrow$ \\
\hline emitted sovereign bonds & $\uparrow$ & devaluation & $\uparrow$ \\
\hline
\end{tabular}

\section{Basic Data and Parameters for the Historical Simulation}

\subsection{Basic Ideas}

As a central assumption it can be stated that interest rate developments and exchange rate volatilities should compensate each other in the long run. This will be analysed empirically in this section. The procedure is as follows: after the explanation of the data used, the distributions of currency yields and the risk/return ratios as well as the correlations will be examined. After that, the three central questions of this paper will be answered:

1. Are currency investments efficient portfolios?

2. Does a portfolio selection considering currency investment lead to a diversified and thus efficient portfolio?

3. Does leveraging a portfolio by refinancing it in another currency lead to an efficient portfolio? 
Only if at least one of these hypotheses can be answered with "yes", currency investments can be treated as an efficient asset class or an efficient leverage class.

\subsection{Defining Representative Currencies}

In order to ensure transparency of the results, only official available data are used. Therefore, historical data from VWD (Vereinigte Wirtschaftsdienste) are used (VWD 2009, pp. 106, $3371-3375,1111,5423,5009)$. Six currencies will be analysed. Table 2 describes them and the reason why they are inserted into this set of representative currencies.

Other currencies as the Russian rouble or the Thailand baht have not been analysed here as the time horizon of the available data is not long enough or the quality of the data is not sufficient for this analysis. This problem affects primarily the interest rate market.

The analysis bases on data from 1994-11-22 up to 2009-09-22. Data with respect to the Czech koruna are available since 1999-01-01, even though the koruna exists since 1993-01-01. Considering the time horizon, the question according to the representativeness of the results has to be answered critically. We think that a 15-year history and a more than 10-year history for the Czech koruna can be treated as nearly representative, even though some results will be relativised later on because of the data used.

Table 2

\section{Analysed Currencies}

\begin{tabular}{|l|l|l|}
\hline Currency & ISO & Reason for choosing the currency \\
\hline Euro & EUR & $\begin{array}{l}\text { The euro is treated as the domestic currency in this article. Further, it } \\
\text { is one of the most important currencies of the world. Before 1999, the } \\
\text { exchange rate of 1.95583 German marks for one euro will be used. }\end{array}$ \\
\hline BS Dollar & USD & $\begin{array}{l}\text { Beneath the euro, the USD has to be mentioned as it is the key } \\
\text { currency for many goods or even countries. Whenever a portfolio } \\
\text { selection is done in an international setup, the USD has to be taken } \\
\text { into account Europe and America stand for two big economies; their } \\
\text { central banks dominate the international interest rate market. }\end{array}$ \\
\hline Swiss Franc & GHF & $\begin{array}{l}\text { Great Britain is one of the few core countries of the European Union } \\
\text { that neglects to introduce the euro as a domestic currency, even } \\
\text { though a high grade of economic integration in Europe has to be } \\
\text { stated. This speciality leads to the analysis of the GBP in this article. }\end{array}$ \\
\hline Japanese Yen & JPY & $\begin{array}{l}\text { The Swiss currency can be stated as a "save haven" in Europe and } \\
\text { represents a special situation as well. Because of the fact that many } \\
\text { investors do not invest into Swiss because of the interest rate level } \\
\text { but because of security reasons, the interest rate remains onto a low } \\
\text { level. The efficiency of a Swiss currency investment has to be doubted } \\
\text { therefore, but leverage by CHF may be a good option to generate an } \\
\text { efficient leverage portfolio. }\end{array}$ \\
\hline Czech Koruna & $\begin{array}{l}\text { This is the reason why the Japanese yen is taken into account as well. } \\
\text { Representing a big economy with a long time of zero interest rate } \\
\text { policy, the JPY may be a good leverage currency as well. }\end{array}$ \\
\hline CZK & $\begin{array}{l}\text { The Czech koruna is a synonym for the euro convergence countries. } \\
\text { The relative young Czech Republic wants to introduce the euro in } \\
\text { some years. An investment into the Czech koruna has thus a limited } \\
\text { tie horizon, but perhaps leverage or a medium-term investment can be } \\
\text { done. }\end{array}$ \\
\hline
\end{tabular}




\subsection{Usable Interest Rates}

In the next step, the interest rate markets have to be defined. For each country, the $1 \mathrm{M}$ (month) and $12 \mathrm{M}$ (month) interest rate will be chosen, using data from VWD as well. The reasons why money market (up to 12 months) and not capital market (from one year to ten years) data is used can be defined as follows:

- Data availability and quality is best according to money markets.

- The money market reacts soonest to exchange rate movements as they are nearest to the key interest rates of a country.

- The chosen money market data represents real interest rates offered inter banks so the liquidity of the market can be assumed

- The money market is a nearly risk free market of the relevant currency. Implementing longer disposition horizons would lead to credit risk effects that must be modelled by credit spreads.

- All other maturities represent an additional asset class: e.g. sovereign or corporate bonds. This would not lead to isolated results according to the currencies themselves.

Last, the assumption of an efficient market has to be made. Both exchange rates and interest rates are mid rates without bid/ask spread. Implementing these effects would lead to inefficiencies of currencies, because the bid/ask spread as to be paid for the currency and the money market rate. All calculations will be done on the mid rates accordingly.

\subsection{Development and Analysis of the Exchange- and Interest Rates}

The long time series used should imply contrary movements of interest rates and exchange rates. Therefore, the analysed $1 \mathrm{M}, 12 \mathrm{M}$ interest rates and the exchange rates are visualized in Figure 1. The left y-axis represents the exchange rate, defined as the amount of currency that has to be paid for one euro. The right y-axis represents the interest rate of the money market. 


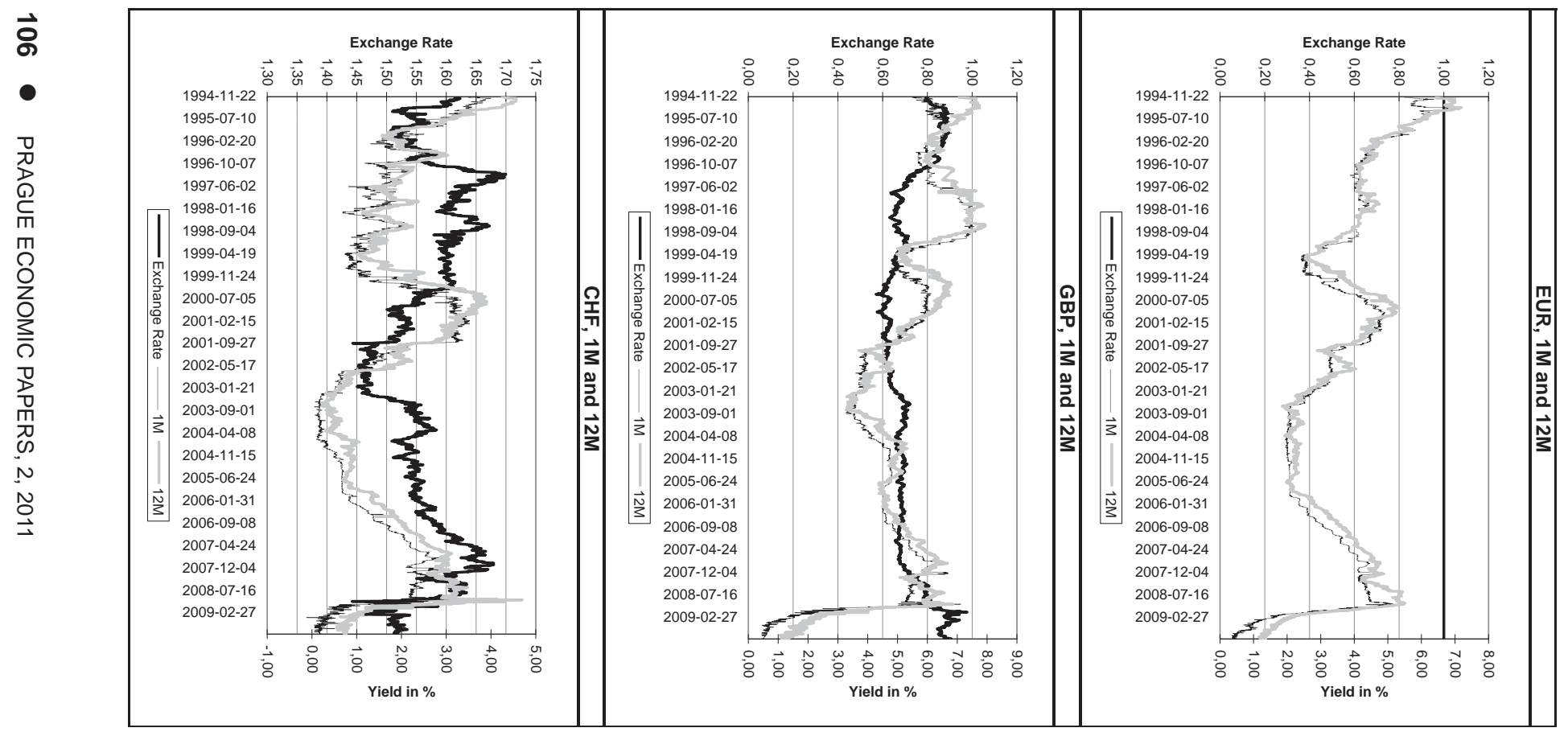




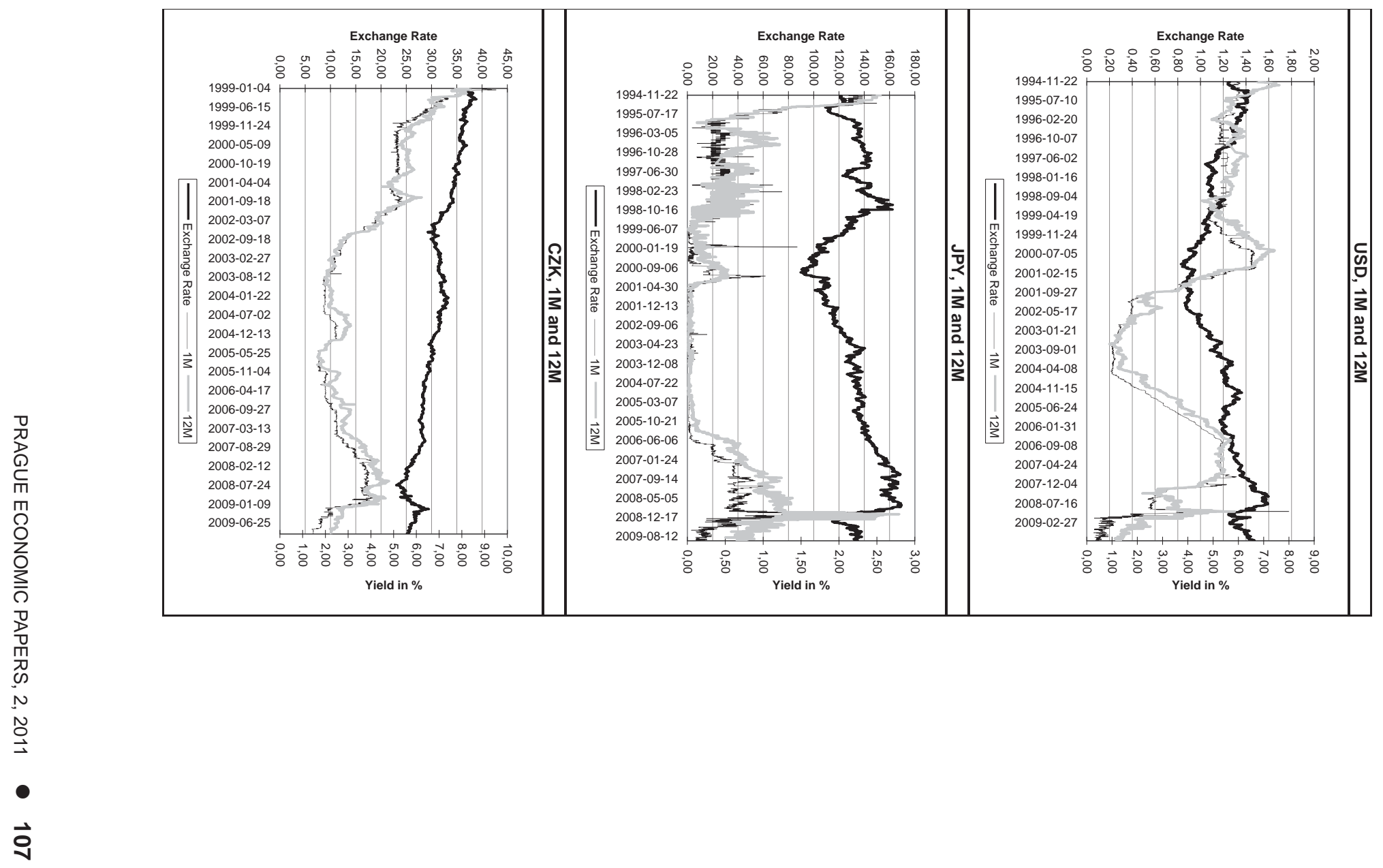


Analysing the developments in a qualitative way leads to the following results. In the euro area, the exchange rate is always one, as it is the domestic currency in this simulation. Further, a similar development of the $1 \mathrm{M}$ and $12 \mathrm{M}$ yield can be stated. The European money market can be defined as very liquid, even though the financial crisis led to a high money demand and to high interest rates accordingly. The fall down since October 2008 results from the reactions of the central banks. The key interest rates fell down since October 2008.

The USD is on a devaluation path since 2000. This corresponds to decreasing interest rates. From 2003, interest rates increase, but the effect onto the USD is low. The shock in the interest rate market in September/October 2008 results from the insolvency of Lehman and the financial crisis. Around the financial crisis, the USD revalued and the interest rates increased. The devaluation afterwards bases on low key interest rates as well.

The British pound moved in a corridor between 0.57 and 0.89. During 2002/2003, devaluations can be stated as well. The reason therefore is a low interest rate level. After the financial crisis, a devaluation of the GBP can be stated. This was combined with lower interest rates.

The Japanese yen is influenced by the zero yield policy of the Japanese central bank since the mid of the 1990s. A clear dependence of interest rate and exchange rate movements cannot be stated. The long period of zero interest rates leads to the conclusion that the yen cannot be an efficient asset class. The focus will be laid on leverage by the JPY.

Interest rates in Switzerland develop similar to Europe, but on a lower level. Dependence between the interest- and exchange rate differentials cannot be stated as well. Only sometimes, higher interest rates are combined with a devaluation of the currency. As the interest rate level is low as well, the CHF might be an efficient leverage class.

The development of the Czech koruna is extraordinary, because the currency is the only one that shows a revaluation path (Svoboda, 2008, p. 274). In addition, this development is combined with increasing interest rates. This development cannot be explained by an isolated exchange rate or interest rate parity theory. One argument for this untypical development is the convergence to Europe, even though we think that this would not happen before 2016. The combination of a revaluation and increasing interest rates leads to the assumption that the Czech koruna is an efficient investment.

Further it has to be stated that $1 \mathrm{M}$ and $12 \mathrm{M}$ interest rates move nearly similar. For the further analysis, the $12 \mathrm{M}$ interest rates will be used. They represent an annual yield and the annual risk better than $12 \times 1 \mathrm{M}$ yield. The latter would have to be annualized, which leads to an inherent model risk as well (Rolfes, 2008, p. 74).

\subsection{Historical Distribution and Main Parameters of Currency Investments}

On the basis of the $12 \mathrm{M}$ market interest rates, investments into the relevant currencies will be simulated in order to generate distribution functions of the currency investments. The procedure is as follows:

1. Investment into a currency, using the relevant exchange rate and $12 \mathrm{M}$ yield of the investment date. 
2. Defining the result of the one year investment, the interests are paid completely after the year (250 trading days).

3. Reconverting the investment including interests back into the domestic currency. By this method, currency and interest rate effects are integrated into the performance.

4. Calculation of the lognormal yield by comparing the results to the basic investment of 100 .

5. Doing step one to four for every available day, assuming a 250 trading day time horizon.

An example is visualized in Table 3. The time horizon is 250 trading days, so the end is not 1995-11-22 but 1995-11-17. This inaccuracy will be accepted further on.

Table 3

Example of the Performance Calculation

\begin{tabular}{|c|c|c|c|c|c|}
\hline \multicolumn{4}{|l|}{ 1994-11-22 } & \multicolumn{2}{|l|}{$1995-11-17$} \\
\hline \multicolumn{2}{|c|}{$\begin{array}{l}\text { EUR/USD exchange rate } \\
\text { Interest rate: }\end{array}$} & \multicolumn{2}{|c|}{$\begin{array}{l}1.2578 \\
6.75 \%\end{array}$} & EUR/USD exchange rate & 1.3950 \\
\hline Investment $t_{t o}$ & & \multicolumn{3}{|c|}{$=100.00 €$} & \\
\hline Investment $_{t 1}$ & \multicolumn{2}{|c|}{$(1+0.0675) * 100 * 1.2578$} & \multicolumn{2}{|c|}{$=96.251 €$} & \\
\hline Performance & $\ln (9$ & & $=$ & $=-3.8211 \%$ & \\
\hline
\end{tabular}

This procedure is done for every currency for the whole historical time horizon. Missing data was approximated by linear interpolation between the existing dates in order to make the results comparable. Further, these performances are analysed according to their expected value, the minimum and maximum of the yield and the $99 \%$ quantile that is defined as a loss quantile and not as a VaR. Table 4 sums up the results of all six currencies. For the CZK, 2,482 yields are available, all other currencies base on 3,506 calculated yields.

Table 4

Basis Data of the Currency Distribution Functions, $n=3,506 /$ CZK 2,482

\begin{tabular}{|l|r|r|r|r|r|r|}
\hline Values & \multicolumn{1}{|c|}{ EUR } & \multicolumn{1}{c|}{ USD } & \multicolumn{1}{c|}{ GBP } & \multicolumn{1}{c|}{ JPY } & \multicolumn{1}{c|}{ CHF } & \multicolumn{1}{c|}{$\begin{array}{c}\text { CZK } \\
\text { (since 01.1999) }\end{array}$} \\
\hline Standard Deviation & $1,120 \%$ & $11,529 \%$ & $9,047 \%$ & $12,771 \%$ & $4,450 \%$ & $5,951 \%$ \\
\hline Historical / Expected Yield & $3,733 \%$ & $4,383 \%$ & $5,364 \%$ & $0,009 \%$ & $2,150 \%$ & $7,142 \%$ \\
\hline Quantile 99\% & $1,980 \%$ & $-20,824 \%$ & $-12,740 \%$ & $-19,648 \%$ & $-7,434 \%$ & $-6,377 \%$ \\
\hline Minimum & $1,833 \%$ & $-24,966 \%$ & $-21,285 \%$ & $-26,458 \%$ & $-9,408 \%$ & $-12,542 \%$ \\
\hline Maximum & $6,941 \%$ & $30,437 \%$ & $34,927 \%$ & $40,482 \%$ & $17,346 \%$ & $23,522 \%$ \\
\hline
\end{tabular}

The next step is to analyse the distribution. Therefore the yields are clustered around the mean with 0.5 standard deviations in order to achieve a discrete frequency distribution. 
This is combined with a continuous normal distribution, using the standard deviation and the mean of the discrete function. The distributions are presented in Figure 3.

The result is that normal distributions in market price risk and currency investments cannot be stated on a significant level (see Reuse, 2010, pp. 85-91 for a corresponding empirical analysis via Jarque-Bera and Kolmogorov-Smirnov). None of the analysed currencies shows an exact normal distribution, even though the tendency to a normal distribution is visible. While CHF, GBP and CZK show positive differences compared to the steady normal distribution, especially the EUR money market investments do not follow a normal distribution. As the EUR is the domestic market and the analysis is done compared to the domestic market, the normal distribution cannot be used. So the historical simulation will be applied onto the relevant data.

Figure 2

Distribution of 12M Currency Yields, $n=3,506$ / CZK 2,482

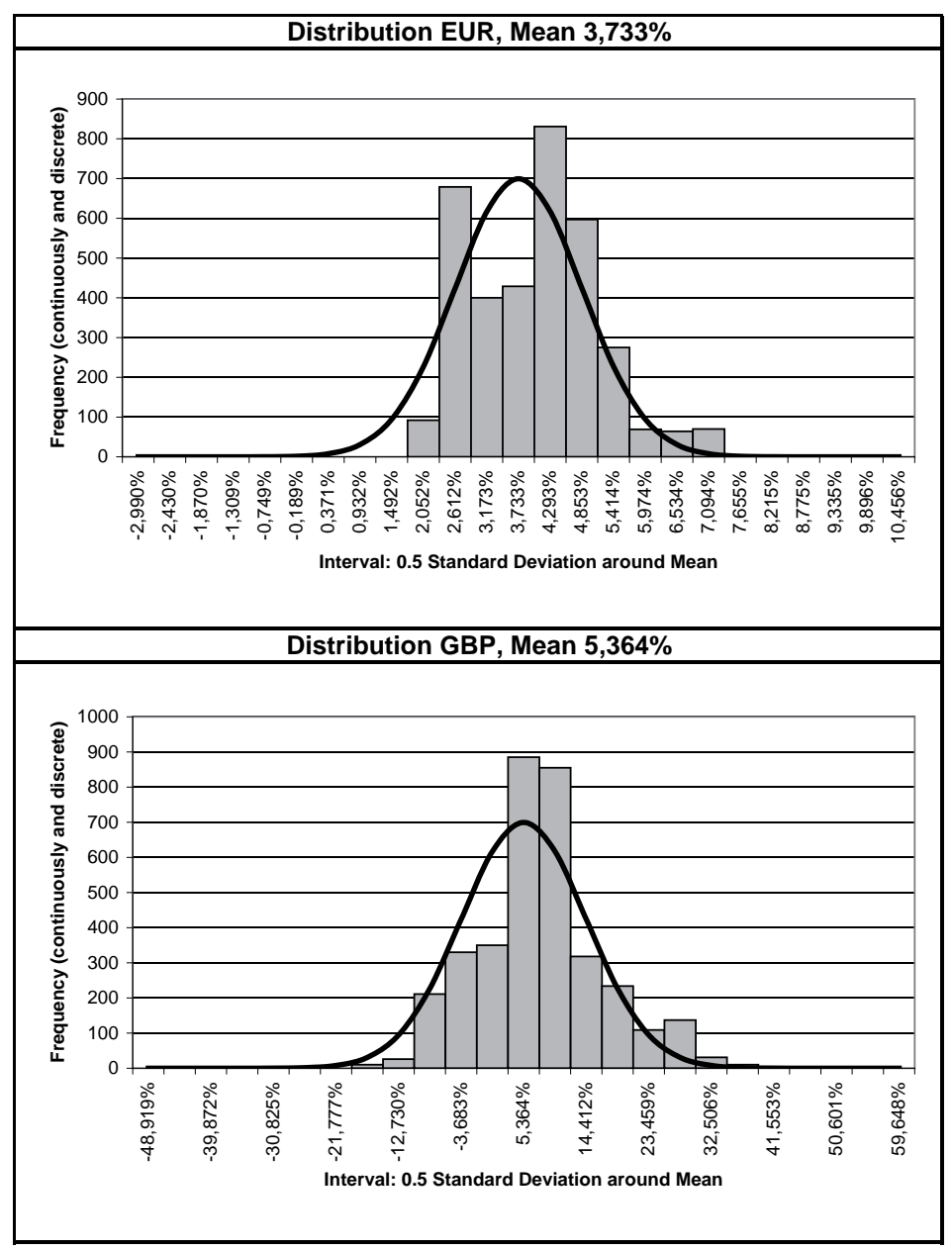




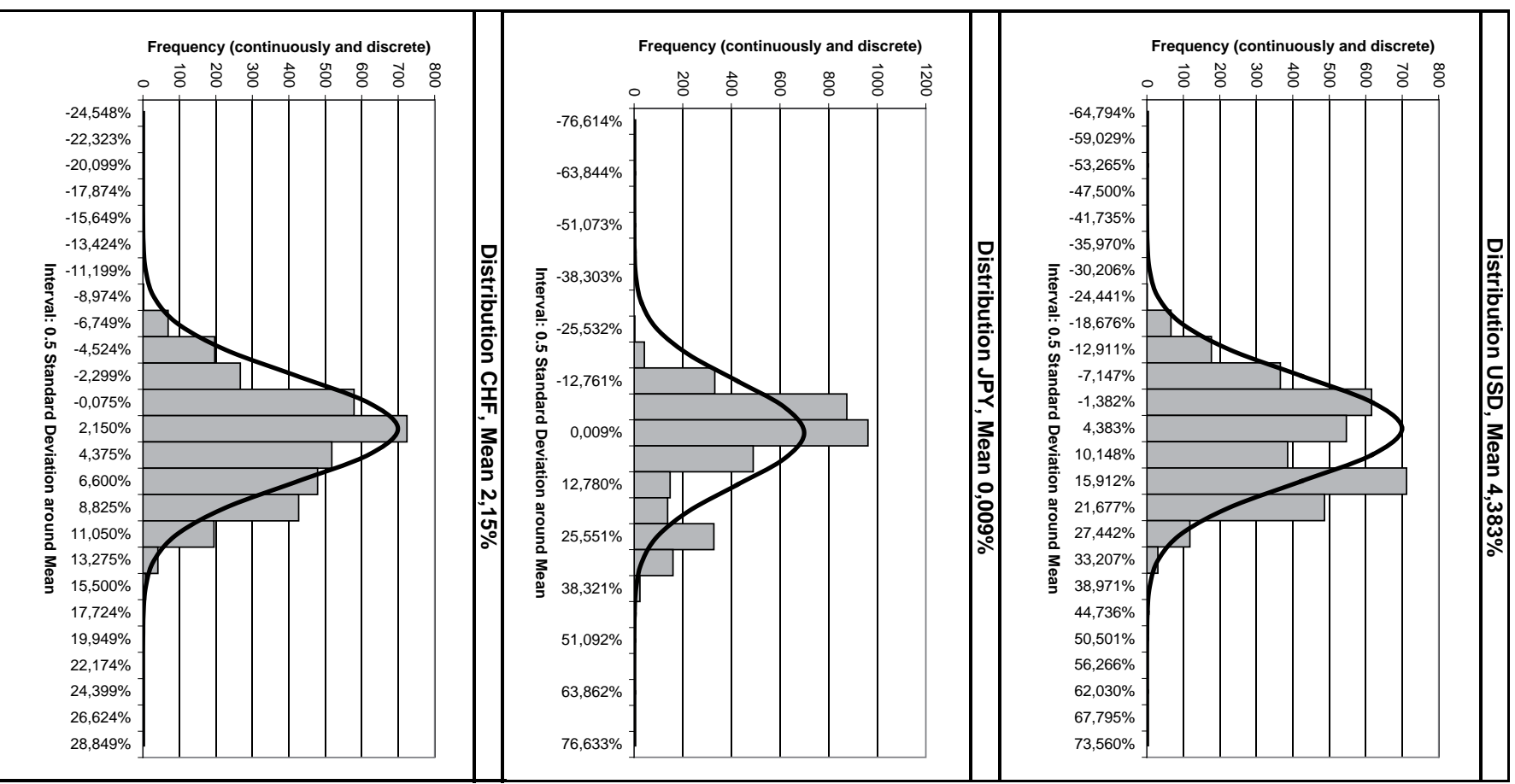

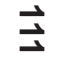




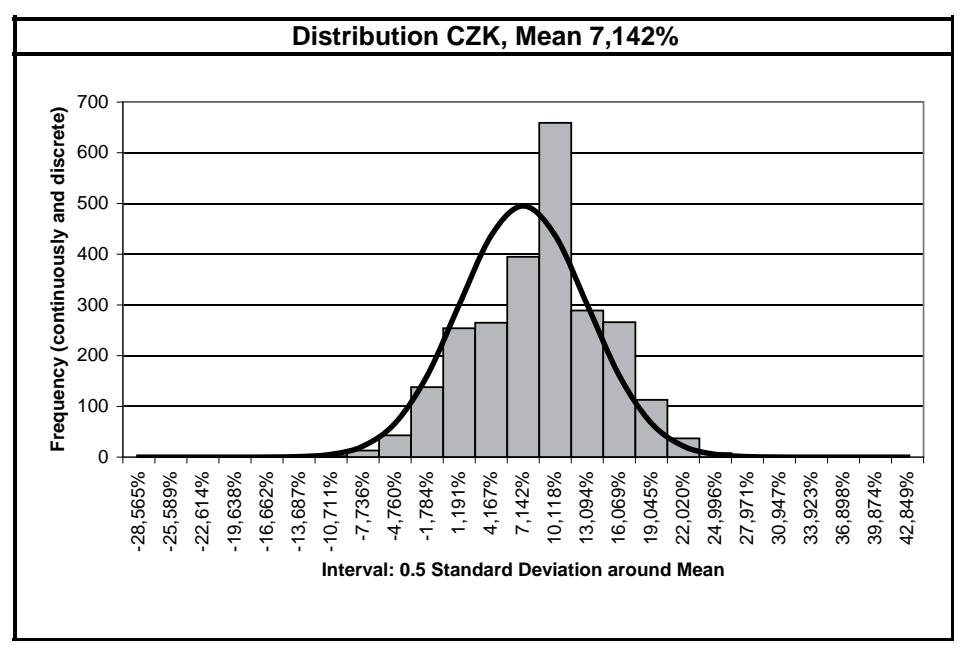

\section{Main Results of the Empirical Historical Analysis}

\subsection{Risk/Return Analysis of an Isolated Currency Investment}

Before analysing the risk/return profile of an isolated currency investment, two additional asset classes will be added. As a representative for share investments, the DAX is introduced and the bond investment is modelled by the RexP. Both indices can be a benchmark or a comparison to currency investments. Later on, they will be used for the international portfolio diversification. Similar to the performance evaluation of the currency investments, risk and return are calculated on the basis of overlapping yearly lognormal yearly performances. Table 5 shows the results.

Table 5

Basis Data of the RexP und DAX Distribution Functions, $n=3,506$

\begin{tabular}{|l|r|r|}
\hline Values & \multicolumn{1}{|c|}{ RexP } & \multicolumn{1}{l|}{ DAX } \\
\hline Standard Deviation & $3,722 \%$ & $28,556 \%$ \\
\hline Historical / Expected Yield & $5,676 \%$ & $5,775 \%$ \\
\hline Quantile 99\% & $-2,818 \%$ & $-66,516 \%$ \\
\hline Minimum & $-4,001 \%$ & $-77,210 \%$ \\
\hline Maximum & $16,066 \%$ & $61,001 \%$ \\
\hline Correlation (on p.a. values) & \multicolumn{2}{|c|}{$-0,348$} \\
\hline
\end{tabular}

The results can be interpreted as follows. The yield of the RexP is higher (5.676\%) than the $12 \mathrm{M}$ yield of $3.733 \%$. This is a quite normal situation, because a positive sloped yield curve should lead to higher returns for long term bonds as e.g. the RexP. 
The yield of the DAX is surprising; it is less than expected (Svoboda, 2008, p. 2). It is nearly at the same level as the RexP yield, even though long term expectations are between $9 \%$ and $11.7 \%$ (DAI, 2008; Reuse, 2007, p. 118). The main reasons are two crashes in the German share market: the new economy bubble and the financial crisis since 2007. In combination with the fact that overlapping yields are used, the history might be stated as too short for a reliable yield of the DAX. This has to be kept in mind, but it does not change the results that follow now.

All assets are analysed according to their RORAC. Therefore, the VaR and RORAC Definitions of section two will be used. As risk is defined as the unexpected difference from an expected value, the expected yield has to be added to the $99 \%$ quantile. Table 6 offers the results.

Table 6

Risk/Return Analysis of All Assets, $n=3,506$ / CZK 2,482

\begin{tabular}{|c|c|c|c|c|c|c|c|c|}
\hline Values & EUR & USD & GBP & JPY & CHF & $\begin{array}{c}\mathbf{C Z K} \text { (sinnce } \\
\text { 01.1999) }\end{array}$ & RexP & $\overline{D A X}$ \\
\hline Standard Deviation & $1,120 \%$ & $11,529 \%$ & $9,047 \%$ & $12,771 \%$ & $4,450 \%$ & $5,951 \%$ & $3,722 \%$ & $28,556 \%$ \\
\hline Historical / Expected Yield & $3,733 \%$ & $4,383 \%$ & $5,364 \%$ & $0,009 \%$ & $2,150 \%$ & $7,142 \%$ & $5,676 \%$ & $5,775 \%$ \\
\hline Quantile 99\% & $1,980 \%$ & $-20,824 \%$ & $-12,740 \%$ & $-19,648 \%$ & $-7,434 \%$ & $-6,377 \%$ & $-2,818 \%$ & $-66,516 \%$ \\
\hline VaR $99 \%$ & $1,753 \%$ & $25,206 \%$ & $18,104 \%$ & $19,657 \%$ & $9,584 \%$ & $13,519 \%$ & $8,494 \%$ & $72,291 \%$ \\
\hline RORAC & $0,000 \%$ & $2,579 \%$ & $9,012 \%$ & $-18,943 \%$ & $-16,513 \%$ & $25,219 \%$ & $22,877 \%$ & $2,825 \%$ \\
\hline
\end{tabular}

The result is that the CZK offers the best RORAC with $25.219 \%$. It is even better than the RexP. The DAX offers a low RORAC because of the low yield. This value has to be seen critical as it should not reflect the long term value.

All other currency assets can be defined as inefficient as the RexP offers a better risk/return profile. Accordingly, the question whether currency investments may be efficient can be answered with no, expecting the CZK. It follows a devaluation trend with increasing interest rates. Even though this development would not go on for eternity, an investor could have realized stable returns over a relative long time period. This leads to the result that convergence countries that had a weak currency before their announcement to introduce the euro can be treated as efficient portfolios. But this effect would, if the euro is introduced.

\subsection{Risk/Return Analysis of Currency Investment in Diversified Portfolios}

The next step is to answer the question, whether currencies may be efficient, if the diversification effect is used. Therefore the correlation coefficients can be used to discuss the diversification effect. This is visualized in Table 7. 
Table 7

Correlation of All Assets, $n=3,506 /$ CZK 2,482

\begin{tabular}{|l|r|r|r|r|r|r|r|l|}
\hline \multicolumn{1}{|c|}{ Correlation } & EUR & \multicolumn{1}{c|}{ USD } & \multicolumn{1}{c|}{ GBP } & \multicolumn{1}{c|}{ JPY } & CHF & $\begin{array}{c}\text { CZK } \\
\text { (since 01.1999) }\end{array}$ & RexP & DAX \\
\hline EUR & 1,000 & & & & & & & \\
\hline USD & 0,296 & 1,000 & & & & & & \\
\hline GBP & 0,002 & 0,604 & 1,000 & & & & & \\
\hline JPY & $-0,038$ & 0,531 & 0,070 & 1,000 & & & & \\
\hline CHF & 0,429 & 0,299 & $-0,308$ & 0,395 & 1,000 & & & \\
\hline $\begin{array}{l}\text { CZK } \\
\text { (since 01.1999) }\end{array}$ & 0,142 & 0,098 & 0,175 & $-0,128$ & 0,175 & 1,000 & & \\
\hline RexP & 0,645 & $-0,058$ & $-0,147$ & $-0,238$ & 0,245 & $-0,128$ & 1,000 & \\
\hline DAX & $-0,263$ & 0,282 & 0,636 & $-0,004$ & $-0,536$ & $-0,094$ & $-0,348$ & 1,000 \\
\hline
\end{tabular}

An analysis of the correlations coefficients leads to the following results. The RexP has its best correlation with the DAX, it is about -0.348. A mixture with currency investments would lead to a diversification as well, but these diversification effects are lower. Finally, a diversification with other currencies does not lead to efficient results as they have a lower RORAC.

In order to visualise this, Figure 3 presents a risk/return profile of all assets. Between the risk free $12 \mathrm{M}$ rate and the RexP and the DAX investment, the efficiency lines simulated by historical analysis are inserted as well. Further, a historical analysis is done for the combinations of RexP with USD, GBP, JPY, CHF and DAX in order to generate the diversification effects. The CZK correlation is implemented as well, but it is calculated with the classical Markowitz formula (Markowitz, 1952, p. 81), using the VaR instead of the standard deviation. This second best choice is used because the time horizon between RexP and CZK differs.

The results can be interpreted in different ways. First it has to be stated that currencies show diversification effect. As every currency is correlated with the most efficient domestic product, the RexP, adding a low part of every currency would lead to less risk. At a first glance, this would lead to the conclusion that currencies help to diversify risk. At a second glance this has to be neglected. If an investor diversifies his RexP portfolio with the DAX, every other currency mixture is inefficient. This corresponds to the quantified correlation in Table 7 . The effect would be clearer, if the yield of the DAX becomes higher. Combined with transaction costs, every currency investment does not make sense - except the CZK investment. Combined with a good RORAC, a diversification of RexP and CZK makes sense; it is the best portfolio combination in our simulation. But it has to be kept in mind that the good RORAC of the CZK might be only a temporary effect up because of the convergence to the EUR. 
Figure 3

Risk/Return Diagram of All Assets, $n=3,506$ / CZK 2,482

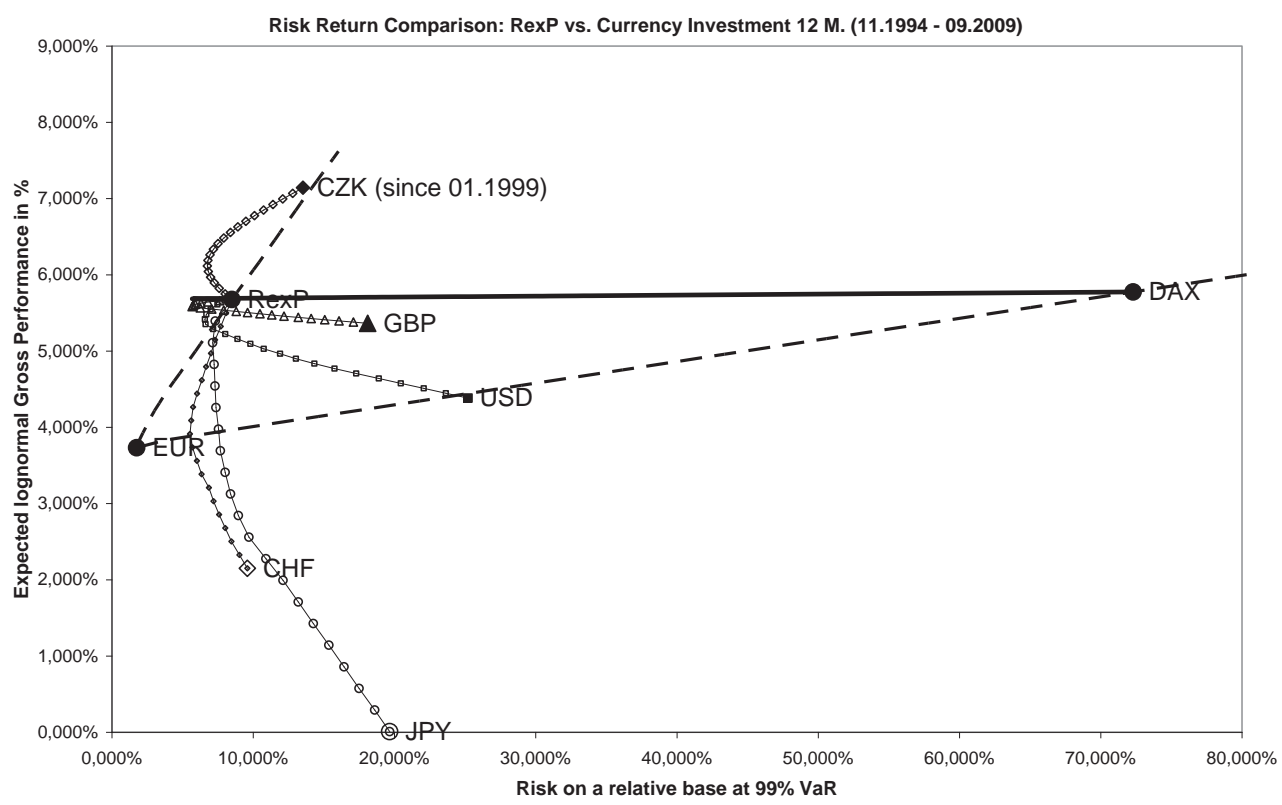

\subsection{Risk/Return Analysis of a Portfolio Leveraged by a Currency}

The last question that has to be answered is, whether leverage by a currency might lead to a better risk/return profile. Therefore the same simulations as above are chosen, but they are modified, as a leverage of more than 1 , which represents leverage by another asset, respectively a short sell, is allowed. The efficient portfolio RexP is refinanced in $5 \%$ steps by $12 \mathrm{M}$ EUR, CHF and JPY, as the last two represent those currencies with the worst RORACs. As the $12 \mathrm{M}$ distributions are not normally distributed, a worse RORAC for an investment does not automatically lead to the conclusion that these assets are good for refinancing. Figure 4 visualizes these effects.

The results may be interpreted as follows. As long as the RexP investment is lower than $100 \%$, a mixture between EUR and RexP is the most efficient combination, even though the JPY is on the efficiency line, if only small parts of EUR or JPY are added. But as soon as a leverage of the RexP takes place, the results differ according to the currency. While the EUR leverage is more efficient than the JPY leverage, the CHF leverage beats both. This differs partly from earlier results (Reuse, 2009). Leverage may be useful if the CHF and not the JPY is chosen. 
Figure 4

Leveraging the RexP by 12M EUR, CHF and JPY

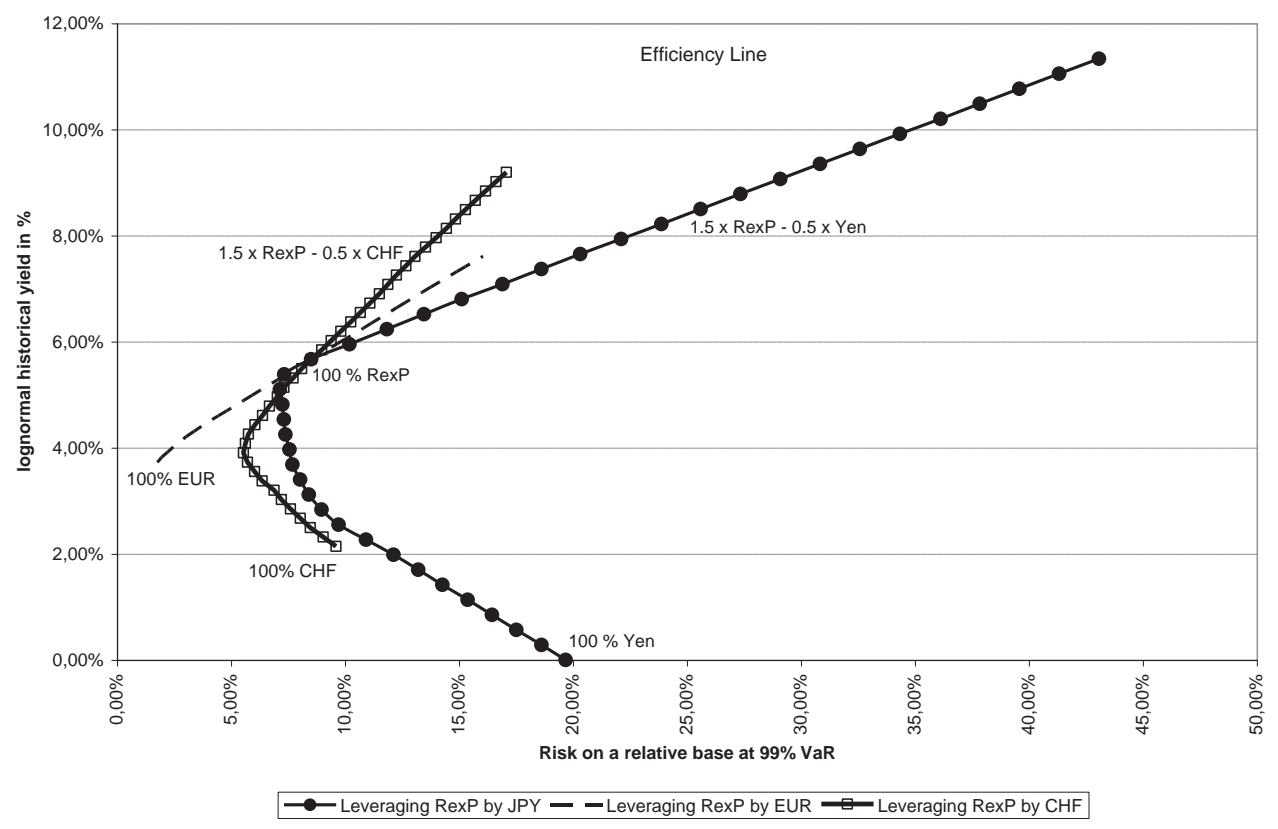

\section{Final Conclusions}

\subsection{Summing up the Main Results}

The three main questions of this article can be answered as follows. It always has to be kept in mind that the result base on a euro-investor's point of view.

1. Currencies cannot be defined as efficient portfolios as long as they are analysed without any diversification effects. The RORAC is worse than other investment forms e.g. the RexP. An exception is the CZK as it shows a higher RORAC than the RexP. We think that it is a temporary effect, assuming that the EUR would be introduced earliest in 2016.

2. Currency investments are able to diversify a portfolio, but on a domestic market, the correlation between the DAX and the RexP beats all other combinations.

3. Leveraging a portfolio by a foreign currency credit is often not efficient. Only with CHF, a better leverage effect can be realised compared to a domestic leverage by EUR.

The basic economic hypotheses that currency movements are neutralised by interest rate changes can be shown by the historical analysis. Only one currency investment is useful for an international portfolio selection. Combined with fact that the CHF revaluated during the last time, the macroeconomic hypotheses can be verified on a weekly base.

One further result is that convergence currencies might over perform since the announcement of introducing the EUR. Similar results can be found in literature. 
A stabilization of the economy of converging countries lead to a stabilization of the currency compared to the EUR (e.g. Friedrich, 2008, p. 119). The CZK is a good example, the simple announcement that the EUR could be implemented in future led to a stabilization path.

Treating currencies as efficient asset classes cannot be verified by this article. Only investing into the CZK and leveraging by CHF beats domestic EUR portfolios. For passive buy and hold investments without leveraging the implementation of currencies shall be neglected. Only in tactic portfolio optimization and in high leveraged portfolios the implementation partly makes sense.

\subsection{Critical Outlook}

The presented results have to be seen critically according to the used data history. On the one hand, the time horizon of even 15 years might be too short as the DAX shows a performance that is less than usually expected. On the other hand, markets converged during the last 15 years, transparency increased and international financial markets became more liquid. This is an argument to neglect a longer time horizon.

Nevertheless it has to be stated that 15 years of history lead to a valid history to answer the theses of this article. Several arguments support the robustness of this analysis:

(1) Even the subprime crisis in 2007 and the insolvency of Lehman Brothers in 09.2008, which can be seen as the start of the financial crisis in 2008, are implemented into the used data. So the data embraces several crises.

(2) The first analysis of the DSGV based on data till 05.2005 . The results were nearly the same - only the leverage efficiency by the CHF was not verified.

(3) An analysis done by Reuse based on data till 11.2008 led to similar results (Reuse, 2009 , p. $273-281$ ) as the DSGV.

To the opinion of the authors, the obtained results are valid for the future as long as the currency market is liquid and none of the analyzed countries becomes insolvent. Such stress tests are not implemented into this analysis.

Further, the results have to be extended by additional arguments. Taxes, transaction costs and liquidity aspects have not been integrated in our research. Further it has to be kept in mind that several other asset classes, e.g. commodities are often traded in USD. So an investor who wants to realize diversification effects by investing in commodities (Linnertová and Reuse, 2008) automatically invests into another currency.

We think that in times of transparent international markets and a more and more harmonized behaviour of the international central banks correlations between markets will become higher and an investment into foreign currencies or leverage by a currency will be inefficient in future. Tactic chances as an investment into CZK or leverage by CHF are only temporary effects that will be regulated in future. A buy and hold investor that does not want to leverage his portfolio should not implement currencies into his portfolio accordingly. 


\section{References}

Blanchard, O., Illing, G. (2003), Makroökonomie (Macroeconomics). Munich: Pearson Education.

Bleuel, H.-H. (2006), "Bestimmung und Steuerung des ökonomischen Wechselkursrisikos." (Definition and Controlling of the Economic Exchange Rate Risk) WISU - das Wirtschaftsstudium, 35(8-9), pp. 1054-1059.

Bühler, W., Korn, O., Schmidt, A. (1998), "Ermittlung von Eigenkapitalanforderungen mit internen Modellen." (Quantification of equity requirements by the use of internal models) Die Betriebswirtschaft 58, pp. 65-85.

Cassel, G. (1932), Theoretische Sozialökonomie. (Theoretic social economics) $5^{\text {th }}$ Ed. Leipzig, Deichert.

Cezanne, W. (1997), Allgemeine Volkswirtschaftslehre (Macroeconomics), $3^{\text {rd }}$ Ed. Munich: Oldenbourg Publishers.

DAI (2008), DAX-Renditen seit 1948 - Das DAI-Rendite-Dreieck (DAX Yields Since 1948 - the DAI Yield Triangle), June 2008.

Dornbusch, R. (1976), "The Theory of Flexible Exchange Rate Regimes and Macroenonomic Policy." Scandinavian Journal of Economics 78(2), pp. 255-275.

Frère, E., Reuse, S., Svoboda, M. (2008), Aktuelle Probleme im deutschen Bankensektor - eine kritische Analyse und mögliche Lösungsansätze. (Actual problems in the German banking sector - a critical analysis of the status quo and possible solutions) Essen: FOM Publishers.

Friedrich, N. (2008), "Währungskredite - Einsatzmöglichkeiten in der Mittelstandsfinanzierung." (Foreign Currency Loans - Usage in the Medium-sized Businesses) in Goeke, M., ed., Praxishandbuch Mittelstandsfinanzierung (Practical Guide Medium-sized Businesses). Wiesbaden: Gabler Publishers, pp. 111-133.

Goebel, R., Sievi, C., Schumacher, M. (1999), Wertorientiertes Management und Performancesteuerung. (Value oriented management and performance controlling) Stuttgart: German Savings Bank Publishers.

Gontermann, A. (2005), "Das monetäre Wechselkursmodell." (The monetary exchange rate model) WISU - das Wirtschaftsstudium, 34(7), pp. 887-890.

Kempa, B. (2001), "Die Zinsparität." (Yield parity) WISU - das Wirtschaftsstudium, 30(7), pp. 954-957.

Krämer-Eis, H. (1998), Evaluierung hoheitlicher Länderrisiken. (Evaluation of sovereign risk) FriedrichSchiller-University of Jena 1998, available fromwww.wiwi.uni-jena.de/Papers/wp-b9801.pdf (Accessed on October $6^{\text {th }}, 2010$.)

Linnertová, D., Reuse, S. (2008), "Using Commodities as a Strategy of Diversification - a Historical Analysis," in Vincent Šoltés, ed., National and Regional Economics VII, Ekonomická fakulta Technickej univerzity v Košiciach, October 3rd, 2008, pp. 554-561.

Markowitz, H. M. (1952), "Portfolio Selection." The Journal of Finance, 7(1), pp. 77-91.

Markowitz, H. M. (1987), Mean-Variance Analysis in Portfolio Choice and Capital Markets. Oxford: Basil Blackwell.

Pohl, M., Schierenbeck, H. (2008), Renditeoptimierung durch die Verbesserung von Risikomodellen. (Yield Optimization by the Improvement of Risk Models). Union Investment Edition risk management 1.6, available from http://institutional.union-investment.de/-snm-01842333541286377624-072b100000-0000000268-1286387224-enm-docme/risikomanagement/isikomana gementordner/4d45826b019c17ad6e29cd211b3a7302.0.0/schierenbeck_081114.pdf (accessed on October $\left.6^{\text {th }}, 2010\right)$.

Reuse, S. (2006), "Berechnung des Value-at-Risk mit der Monte-Carlo-Simulation." (Quantification of the VaR by the usage of the Monte-Carlo-Simulation) Bankpraktiker, 1(7-8), pp. 366-371.

Reuse, S. (2007), Corporate Evaluation in the German Banking Sector. Wiesbaden: DUV Gabler Publishers. 
Reuse, S. (2008), "Definition und Ausprägung des Zinsänderungsrisikos (Definition and structure of interest rate risk." in Fröhlich, J., Geiersbach, K., Prasser, S., Rassat, T., Reuse, S., Steinwachs, P. eds., Zinsrisikomanagement. Heidelberg 2008, pp. 1-16.

Reuse, S. (2009), "Sind Währungen effiziente Assetklassen? Eine kritische historische Analyse auf Basis der Portfoliotheorie." (Are Currencies Efficient Asset Classes? A Critical Historical Analysis on the Basis of the Portfolio Theory) Finanzbetrieb 11(5), pp. 273-281.

Reuse, S. (2010), "Distribution of Share and Bond Prices - an Analysis with the Kolmogorov-Smirnov and Jarque Bera test via MS Excel at the Example of the German RexP and DAX." 2nd International PhD Conference - New Economic Challenges. 20.01.2010 - 21.01.2010, Brno 2010, pp. 85-91.

Rittenbruch, K. (1995), Makroökonomie. (Macroeconomics), $9^{\text {th }}$ Ed. Munich: Oldenbourg Publishers.

Rolfes, B. (2008), Gesamtbanksteuerung. Stuttgart: Handelsblatt Publishers.

Schierenbeck, H. (2001), Ertragsorientiertes Bankmanagement (Performance-oriented Bank Controlling), No. 2. $7^{\text {th }}$ Ed. Wiesbaden: Gabler Publishers.

Sharpe, W. F. (1964), "Capital Asset Prices, A theory of Market Equilibrium under Conditions of Risk." Journal of Finance 19(3), pp. 425-442.

Sharpe, W. F. (1994), "The Sharpe Ratio." Journal of Portfolio Management, fall 1994, pp. 49-58.

Svoboda, M. (2008), Index Investing. Brno: Computer Press. 